\title{
Do Industrialized Countries Hold the Right Foreign Exchange Reserves?
}

\author{
Linda Goldberg, Cindy E. Hull, and Sarah Stein
}

That central banks should hold foreign currency reserves is a key tenet of the post-Bretton Woods international financial order. But recent growth in the reserve balances of industrialized countries raises questions about what level and composition of reserves are "right" for these countries. A look at the rationale for reserves and the reserve practices of select countries suggests that large balances may not be needed to maintain an effective exchange rate policy over the medium and long term. Moreover, countries may incur an opportunity cost by holding funds in currency and asset portfolios that, while highly liquid, produce relatively low rates of return.

G overnments around the world hold official foreign exchange reserves, which consist of foreign currencies, foreign government securities, and other foreign currency assets. Most often these reserves are held by central banks, although in some cases they may be held by finance ministries or sovereign wealth funds. To date, the foreign exchange reserves of major industrialized economies have received relatively little attention in public policy circles, with few questions posed regarding their optimal size, composition, and use. Instead, discussion of foreign exchange reserves tends to center on the large holdings of emerging market countries - including China, whose reserves reached about $\$ 3$ trillion in mid-2012. Foreign currency reserves are also overshadowed in public discussion by the much larger external imbalances that countries amass in the form of trade deficits and surpluses.

While industrialized countries have not accumulated the high level of reserve balances held by some emerging market countries, they have, in a number of cases, seen their reserve balances grow over the past decade. Some industrialized countries have built reserves in periods of current account surpluses or as part of their efforts to resist the appreciation of their currency. In the case of others, the growth of reserves has been more passive- the accrual, over time, of investment returns on a pre-existing stock of reserve assets. Even these gradual gains, however, can add up, producing a significant increase in reserves. The possibility of such significant accumulations raises some fundamental questions for industrialized countries: Are high reserve balances desirable? How effectively do such balances serve the purposes that the countries have assigned to them? And how can reserve balances be reduced if they have grown to undesirable levels?

This edition of Current Issues provides a conceptual treatment of the size and composition of industrialized countries' foreign exchange reserves. We consider why countries hold such reserves, and argue that while the scale of international financial and currency transactions has grown tremendously over time, it does not necessarily 
follow that the reserve balances of industrialized countries should expand correspondingly. Higher reserve balances have opportunity costs: most notably, they may yield lower returns than some alternative uses of these funds. Moreover, it is not evident that large foreign exchange reserve balances are needed for effective policy over the medium- and long-run horizons of countries. To place the discussion of these issues in context, we turn in the second half of the article to the experiences of six industrialized countries - the United States, the United Kingdom, Switzerland, Japan, Canada, and the euro area ${ }^{1}$ — in acquiring and holding foreign exchange reserves.

\section{Why Do Industrialized Countries Hold \\ Foreign Exchange Reserves?}

Industrialized countries hold foreign exchange reserves as a tool for influencing their exchange rates. Under a fully flexible exchange rate system, the price of a country's currency - the exchange rate-appreciates or depreciates so that the supply of the currency equals the demand for it. In such an environment, countries seldom use foreign exchange reserves. But suppose instead that a country wishes to resist the movements in the exchange rate of its currency. A change in the price of the country's currency can be averted if the excess demand for, or supply of, the currency is absorbed by the foreign exchange balances in the portfolio of the central bank. For example, consider a country that is running a balance of payments deficit-meaning that cash outflows exceed inflows on all transactions between that country and the rest of the world. To avoid a depreciation of the currency, the central bank can sell foreign exchange reserves and buy up the excess supply of the country's currency. Alternatively, in a balance of payments surplus environment, a central bank can avoid a currency appreciation stemming from excess demand for the country's currency by selling domestic currency and accumulating foreign exchange reserves. These actions by the central bank-accumulating or selling off foreign exchange to control the exchange rate-are termed official foreign exchange interventions.

Countries may also hold foreign exchange reserves in the expectation that the reserves might be used to calm disorderly markets. For example, the threat of intervention by the central bank may restore a perception of two-sided risk to a market in which speculators are betting that the exchange rate will move exclusively in one direction, toward depreciation or appreciation.

A third reason that countries may maintain reserve balances is to insure against liquidity losses and disruptions to capital market access. Aizenman (2008) argues that this self-insurance motive drove the rapid accumulation of reserves in Asia in the early 2000s, in the aftermath of the East Asian crisis.

\footnotetext{
${ }^{1}$ For expository purposes, we refer to the euro area as a "country" because foreign exchange reserves in the euro area are held at the European Central Bank. While some of the central banks in the euro-area member countries also have foreign exchange reserves, these funds are generally not used in foreign currency interventions and are therefore excluded from this discussion.
}

What Is the "Right" Level of Reserves

for Industrialized Countries?

Defining the right level of reserves for an industrialized country is difficult. As we have seen, reserve holdings are expected to provide significant benefits, enabling countries to intervene in foreign exchange markets and to regulate the value of their currency. But reserve accumulations also entail certain costs. Among these is the opportunity cost of maintaining funds in currency and asset portfolios that produce returns lower than those of many alternative investments. ${ }^{2}$ Most industrialized countries mandate that reserves be invested in highly liquid assets such as foreign government securities; while these assets provide insurance against a loss of access to the capital markets, they generally yield relatively low rates of return. Of course, the larger the

\section{Reserve holdings are expected to provide significant benefits, enabling countries to intervene in foreign exchange markets and to regulate the value of their currency. But reserve accumulations also entail certain costs.}

portfolios, the greater the overall opportunity cost of these low returns compared with returns on alternative uses of the funds. Moreover, the larger the reserve balances, the greater the exposure of central bank portfolios and, ultimately, taxpayers to moves in exchange rates when these realignments ultimately occur.

Authoritative metrics on the ideal level of foreign currency reserves needed by industrialized countries are not readily available. So it is useful to ask-particularly in light of the opportunity costs we have identified - how much benefit a country really derives from maintaining large reserve balances for possible future intervention activities. Are foreign exchange interventions in fact effective for maintaining a desired level or trajectory of exchange rates? Moreover, how many reserves would be needed for these interventions?

Academic researchers studying episodes of foreign exchange intervention activity have reached mixed conclusions on the effectiveness of the interventions in influencing levels of exchange rates for more than a short period of time. ${ }^{3}$ One reason to be skeptical of this influence is that the volumes of foreign exchange market transactions are very large in comparison with the sizes

\footnotetext{
${ }^{2}$ We do not address the distribution of costs and benefits in limiting the movements of one currency in relation to other currencies.

${ }^{3}$ For an overview of the different arguments about currency intervention and a survey of evidence through the 1990s, see Sarno and Taylor (2001). A more recent survey by Menkhoff (2010) uses high-frequency data to examine the effects of intervention on prices and volatility. Even those who are skeptical of the efficacy of intervention activity acknowledge the potential usefulness of retaining the option for foreign exchange intervention as one part of a broader toolkit (Truman 2003).
} 
of most foreign exchange interventions conducted by central banks. Indeed, the average daily spot market over-the-counter foreign exchange turnover is nearly $\$ 1.5$ trillion per day (Bank for International Settlements 2010). Clearly, total reserve balances on the order of tens or even hundreds of billions of dollars are small relative to daily turnover volumes.

Such broad-based grounds for skepticism aside, some researchers have undertaken analyses to rank individual types of foreign exchange interventions by their effectiveness in moving exchange rates (Dominguez 2003, 2006). For industrialized countries, it appears that the most effective intervention activitiesdefined in terms of magnitude and persistence of exchange rate effects—are those that are coordinated across major currencies, publicly announced, and "unsterilized," meaning that the central bank does not conduct open market operations to neutralize the consequences of the intervention for domestic money supplies. Researchers have also examined how these interventions actually affect exchange rates. Some contend that the effects of intervention work through portfolio channels - that is, the interventions influence exchange rates by changing the relative supply of currencies and related assets in the hands of private investors. Others argue that the strongest effects of foreign exchange interventions occur through "signaling" channels. In other words, the interventions are viewed as communicating the intentions of domestic and foreign policymakers with respect to monetary aggregates. The most effective signals, the research suggests, are those consistent with the intended path of future interest rates.

Interestingly, the studies of foreign exchange intervention do not offer a clear account of the level of foreign exchange reserves needed to intervene in foreign exchange markets for the purpose of influencing exchange rates. Hence, a bit of a paradox arises. Suppose signaling is the most effective channel for foreign exchange intervention effects on exchange rates. How much foreign currency must be bought or sold in foreign exchange markets - if any - to achieve a viable signal of policy intention? Perhaps the purchase or sale of a small amount of reserves would be enough to send the appropriate message, as long as this transaction was accompanied by a clear statement of intent on exchange rate goals and monetary trajectories. A minimalist approach to intervention activity might be particularly effective when interventions are coordinated across countries.

These arguments are relevant for countries that seek to resist appreciation or weaken the value of their currencies-including those countries facing large capital inflows and currency appreciation pressures because their currencies are regarded as "safe havens." Certainly, a central bank can provide the extra domestic currency demanded by markets, buy up foreign currency, and accumulate substantial holdings in official reserve accounts. Yet it may be the case that policymakers do not need to use foreign exchange reserves to achieve their goals. As an alternative to this type of foreign exchange accumulation, policymakers could implement - if feasible - expansionary monetary policies. However, such expansionary policies entail their own costs and benefits, which would have to be weighed.

Central banks that acquire a large stock of reserves through foreign exchange interventions, purchasing foreign currency in return for (an elastically supplied) domestic currency, face another, longer-term issue. Once reserve balances become high, the central bank may need to identify an exit strategy. This exit strategy defines the path that should be pursued to return foreign exchange reserve holdings to less elevated levels. The strategy chosen depends in part on the circumstances surrounding the initial growth of reserves. If reserves grew as part of a central bank's effort to offset the exchange rate effects of safe-haven inflows from a transitory risk event in another country, the central bank might wait until the excess inflows have reversed, and then sell foreign exchange reserves in a way that minimizes appreciation pressures on its own currency. Exchange rate impacts may be weaker when such sales are conducted without signal content and without coordination across countries - though too few episodes of such reserve balance "unwinding" have been explored by researchers to produce evidence definitively supporting this

Most industrialized countries mandate that reserves be invested in highly liquid assets such as foreign government securities; while these assets provide insurance against a loss of access to the capital markets, they generally yield relatively low rates of return.

approach. In general, operations guided by principles such as transparency, predictability, and gradualism may be less likely to have undesirable signaling content and, for this reason, are less likely to have large impacts on the exchange rate.

Foreign exchange interventions in which the central bank seeks to counter a currency depreciation represent a much less sustainable strategy than interventions aimed at resisting currency appreciation. In responding to depreciation pressures, a central bank has finite stocks of foreign exchange reserves that can be depleted rapidly by speculative activity in foreign exchange markets betting on currency depreciation. Persistent sales of foreign currency in support of a domestic currency would drain foreign exchange reserves quickly to some floor level. Hence, the sale of reserves might end up being just a transitory measure that has no lasting effect on currency values. To ensure that the intervention will have a more lasting effect, the central bank will probably want to rely on the signaling channel. The most effective signals are those coming from convincing guidance on monetary policy and credit conditions across countries. 
In both appreciation and depreciation episodes, exit strategies from suboptimal reserve balances - whether too high or too low-pose difficulties because they may distort prices for a period of time. Accumulated reserves above and beyond normal levels for countries are presumably excessive from a longer-run perspective, raising the issue of how best to reduce balances and minimize the resulting period of exchange rate distortions. Likewise, when reserves are depleted and below desired levels, they can be difficult to replenish unless exchange rates are maintained at levels that keep the home currency more depreciated than market forces would otherwise dictate.

Another issue relevant to optimal reserve quantities pertains to the insurance motive. Some of the demand for reserves as insurance against liquidity losses could be mitigated by other options available to industrialized economies in the event of a liquidity disruption. In 2007 and 2008, a number of bilateral measures were arranged across central banks to alleviate funding pressures in their domestic currencies. One such measure was the central bank network of swap lines (see McGuire and von Peter [2009]). For example, the Federal Reserve's foreign exchange swaps program allowed some countries to address disruptions to U.S. dollar funding markets for local institutions rather than deploy their foreign exchange reserves (see Goldberg, Kennedy, and Miu [2011]). A group of central banks that have entered into various bilateral swap agreements may reduce the need for their own reserve accumulations, although the provision of large amounts of currency and the establishment of lines across other central banks are not always made as long-term commitments.

\section{Central banks that acquire a large stock of reserves through foreign exchange interventions ... face another, longer-term issue. Once reserve balances become high, the central bank may need to identify an exit strategy.}

Significantly, these swap lines are not aimed at funding foreign exchange intervention or adjustments to the exchange rate. The International Monetary Fund's Flexible Credit Line is also designed for insurance purposes.

\section{The Experiences of Six Industrialized Economies}

To examine in more concrete terms the issues surrounding industrialized country reserve holdings, we consider the experiences of a few advanced countries: Canada, Japan, Switzerland, the United Kingdom, the United States, and the euro area. The foreign exchange reserve balances of these economies have grown over the past decade (Chart 1). ${ }^{4}$ However, the reserve growth

\footnotetext{
${ }^{4}$ Other central bank reserve assets include gold, special drawing rights, and International Monetary Fund reserve positions. It is mainly the foreign
}

\section{Chart 1 \\ Foreign Exchange Reserves of a Sample of Industrialized Countries}

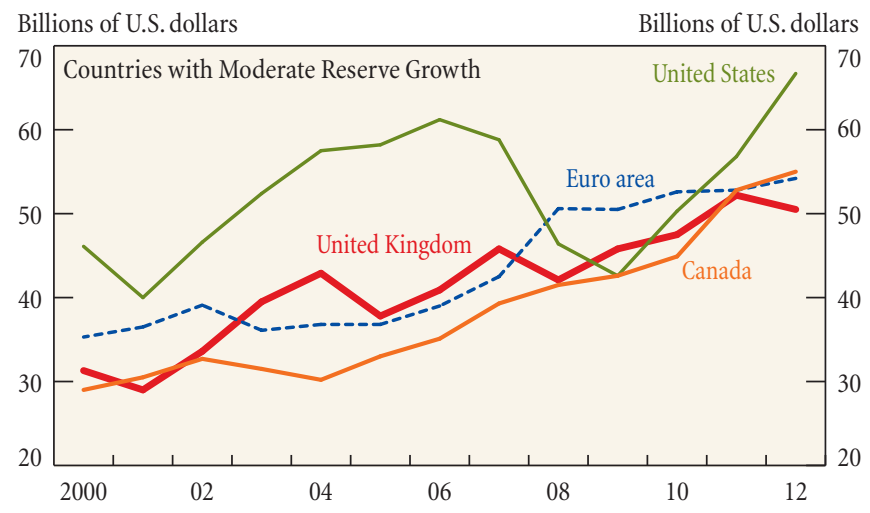

Billions of U.S. dollars Billions of U.S. dollars

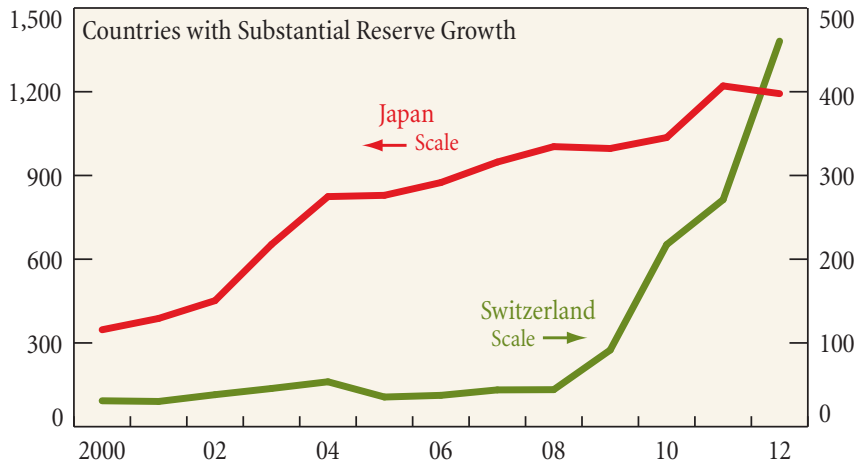

Source: International Monetary Fund, Data Template on International Reserves and Foreign Currency Liquidity.

rates, levels, and sources of reserve accumulation differ markedly across two subsets of these countries. The United States, Canada, the euro area, and the United Kingdom have similarly sized reserves holdings, ranging from $\$ 50.5$ billion (for the United States) to $\$ 66.7$ billion (for the United Kingdom) at the end of 2012. Each of the four countries experienced gains in their reserve holdings over the decade, ranging from a 39 percent increase in the reserves held by the European Central Bank to a more substantial 68 percent increase in the reserves held by the Bank of Canada. For these countries, reserve increases have stemmed primarily from market-based fluctuations in exchange rates between U.S. dollars and euros or yen, from capital gains, and from interest accrued on investment portfolios.

The size and the growth rates of foreign currency reserves for Japan and Switzerland are distinctly greater. Between 2000 and 2012, Japan's foreign exchange reserves increased more than 250 percent, to $\$ 1.2$ trillion; Switzerland's rose to $\$ 460$ billion,

Footnote 4 (continued)

exchange reserves component that is actively managed and used for most official transactions. 
with the sharp expansion in holdings taking place largely since 2008. While the accumulation of foreign exchange reserves in the other industrialized countries under discussion is traceable to valuation and growth effects on pre-existing portfolios, the accumulation of reserves in Japan and Switzerland is tied to the exchange rate objectives that the two countries have actively pursued through purchases of foreign currency and sales of domestic currency in foreign exchange markets.

Foreign exchange reserves have only rarely been used for intervention purposes by Canada, the United Kingdom, the euro area, and the United States in the past two decades (see the appendix table). Instead, exchange rates have been allowed to fluctuate in line with the excess demand for, or supply of, these countries' currencies. A recent exception occurred on March 18, 2011, when these countries intervened collaboratively to weaken the yen in the aftermath of Japan's earthquake and tsunami. This action, conducted jointly with Japan, was designed to counter excessive volatility and disorderly movements in the value of the yen. Prior to this action, these four countries had not intervened in foreign exchange markets since the coordinated effort to support the euro in 2000. This rare use of the intervention tool in recent decades explains why the growth of reserve balances in these countries stems mainly from valuation changes in portfolio assets and the returns on these investments.

Japan and Switzerland, by contrast, have been much more active in using their foreign exchange reserves to influence the values of their currencies. For Japan, this type of intervention prevailed in periods from the 1970s through the 1990s when pressure for substantial appreciation of the yen met with concomitant concerns in Japan that such currency movements would hurt the competitiveness of the country's exports in world markets. As a result of Japan's efforts to resist further appreciation in the mid1990s, reserves grew significantly between 1990 and 2000. Then, from 2000 through 2004, Japan's Ministry of Finance regularly conducted foreign exchange interventions. These interventions eventually tapered off, but were revived in September 2010. Japan attempted to further weaken the yen with unilateral interventions in August 2011 and between October and November 2011.

Swiss activity in foreign exchange market intervention essentially began in March 2009 when the Swiss National Bank (SNB) began a year-long series of interventions aimed at resisting further appreciation of the Swiss franc. Then, in September 2011, the SNB committed to keeping the euro-franc exchange rate above a minimum level of 1.20 Swiss francs per euro regardless of the corresponding build-up in foreign currency reserves. The foreign exchange reserve accumulation continued as investors sold euros for Swiss francs and these euro assets were added to the balance sheets of the Swiss official sector. The foreign exchange reserve accumulation was not itself the goal of policy, but instead was a by-product of the exchange rate and monetary policy objectives set in place and of the safe-haven flows out of euros.
Table 1

\section{Sample Countries' Objectives in Holding Foreign Currency Reserves}

\begin{tabular}{ll}
\multicolumn{1}{c}{ Country } & \multicolumn{1}{c}{ Official Statement } \\
\hline Canada & "The legislative objective of the EFA [Exchange Fund \\
Account], specified in Part II of the Currency Act, is to aid \\
in the control and protection of the external value of the \\
Canadian dollar. Assets held in the EFA are managed to \\
provide foreign currency liquidity to the Government and \\
to promote orderly conditions for the Canadian dollar in the \\
foreign exchange markets, if required." \\
"Foreign exchange reserves are held on a precautionary \\
basis - to meet any change in exchange rate policy in the \\
future, if required, or in the event of any unexpected shocks. \\
The reserves are also used to provide foreign currency \\
services for government departments and agencies, to provide \\
foreign exchange for making payments abroad, and to buy, \\
sell, and hold Special Drawing Rights (SDRs) as required by \\
the UK's membership in the IMF [International Monetary \\
Fund]." \\
"[The objective of reserves is to] ensure sufficient liquidity \\
in order to be prepared for purchases and sales of foreign \\
exchange, etc., needed to secure the stability of Japan's \\
currency." \\
"The main purpose of the ECB’s [European Central Bank's] \\
Japan \\
foreign reserves is to ensure that, whenever needed, the \\
Eurosystem has a sufficient amount of liquid resources for its \\
foreign exchange policy operations involving non-EU [non- \\
European Union] currencies." \\
"[The Swiss National Bank's currency reserves] engender \\
confidence in the Swiss franc, help to prevent and overcome \\
crises and may be utilized for interventions in the foreign \\
exchange market.... The SNB holds currency reserves in the \\
form of foreign exchange and gold in order to ensure that it has \\
room for manoeuvre in monetary policy at all times." \\
"System operations in foreign currencies shall generally be \\
directed at countering disorderly market conditions, provided \\
that market exchange rates for the U.S. dollar reflect actions \\
and behavior consistent with IMF Article IV, Section 1."
\end{tabular}

Sources: Department of Finance Canada, Report on the Management of Canada's Offcial International Reserves, April 1, 2008-March 31, 2009; Her Majesty'sTreasury, Debt and Reserves Management Report, 2010-11; Ministry of Finance Japan, "Guidelines for the Management of Foreign Assets Held in the Foreign Exchange Fund Special Account," April 2005; European Central Bank, Annual Report 2009; Swiss National Bank, 102nd Annual Report, 2009; Board of Governors of the Federal Reserve System, "Foreign Currency Directive," Minutes of the Federal Open Market Committee, January 26-27, 2010.

\section{Official Statements on Holding Reserve Balances}

The size and composition of the sample countries' reserve balances can be considered in relation to the countries' official statements of their objectives in holding foreign currency reserves. These statements, presented in Table 1, generally characterize holdings of foreign currency reserves as a means of protecting the value of a country's currency and managing excess foreign exchange market volatility. In addition, specific language in some statements covers additional objectives, including retaining liquidity for foreign exchange policy operations. 
While evaluating reserve balances against countries' reported objectives makes sense in principle, it is difficult to assess how the scale of the reserve balances held by the United States, the euro area, the United Kingdom, and Canada matches the official objectives. Is a balance of $\$ 50$ billion or $\$ 100$ billion large or small in the context of these objectives? As we observed earlier, these balances are not large relative to foreign exchange market turnover. Still, they are likely large enough to deal with short-term volatility in exchange rates and to signal a central bank's intentions about policy and commitments to policy goals. To be sure, a signal may be viewed as more credible if reserve balances are larger and more visible. But it is also possible that these balances are larger than they need be for the objectives of policy. In the case of Japan and Switzerland, it is even more likely that balances have grown beyond the desired size as reserve portfolios have expanded to many times their historical levels and now significantly exceed the balances of the other industrialized countries.

Currency Composition, Approved Assets, and Opportunity Costs The composition of reserve holdings has also evolved over the past decade. To be sure, the majority of industrialized country reserves continue to be invested in U.S. dollars, euros, and Japanese yen. (Of the six countries in our sample, only Switzerland chooses to hold other foreign currency assets, with the portfolio potentially including British pounds, Canadian dollars, and Danish kroner.) However, the share of dollar assets held by the major central banks (with the exception of the Bank of Canada) has declined. Although neither the euro nor the yen has supplanted

\section{Japan and the United States can invest their reserves in a relatively narrow group of assets, while other countries - Canada, the euro area, and Switzerland-have actively introduced broader investment opportunities for their portfolios.}

the dollar as the dominant reserve currency, the shares of euro and yen assets in central bank portfolios have grown as the dollar asset share has fallen. For Switzerland, the growth of euros in the reserve portfolio in recent years is at least partially the result of the central bank's interventions (discussed above) to keep the euro-Swiss franc exchange rate above a minimum level.

The foreign exchange reserve managers in each country follow a range of approaches to establish the currency composition of the overall portfolio. At one end of the spectrum, the Bank of England has a publicly stated target allocation of 40 percent dollars, 40 percent euros, and 20 percent yen. At the Bank of Canada, the currency composition of the reserve assets is specified within the country's asset-liability management framework, which dictates
Table 2

\section{Share of Foreign Currency Assets in Central Bank Portfolios}

Percent

\begin{tabular}{|c|c|c|c|c|c|c|c|c|}
\hline \multirow[b]{2}{*}{ Country } & \multicolumn{2}{|c|}{$\begin{array}{l}\text { U.S. Dollar } \\
\text { Assets }\end{array}$} & \multicolumn{2}{|c|}{ Euro Assets } & \multicolumn{2}{|c|}{$\begin{array}{c}\text { Japanese Yen } \\
\text { Assets }\end{array}$} & \multicolumn{2}{|c|}{ Other Assets } \\
\hline & 2000 & 2011 & 2000 & 2011 & 2000 & 2011 & 2000 & 2011 \\
\hline Canada $^{a}$ & 49.4 & 60.4 & 47.3 & 39.3 & 3.3 & 0.3 & 0 & 0 \\
\hline United Kingdom & 36.2 & 28.3 & 41.9 & 59.1 & 21.9 & 12.6 & 0 & 0 \\
\hline Euro area & 96 & 76.9 & - & - & 4 & 23.1 & 0 & 0 \\
\hline Switzerland ${ }^{\mathrm{b}}$ & 40 & 26 & 44 & 52 & 4 & 9 & 12 & 13 \\
\hline United States & - & - & 47 & 53 & 53 & 47 & 0 & 0 \\
\hline
\end{tabular}

Sources: Department of Finance Canada, Report on the Management of Canada's Official International Reserves, 2003-11; Bank of England, U.K. International Reserves and Foreign Currency Liquidity Template; European Central Bank, annual reports, 2006-11, and "Portfolio Management at the ECB," Monthly Bulletin, April 2006; Swiss National Bank, annual reports, 2000-11; Federal Reserve Bank of New York.

Note: The numbers in the table are presented as reported in the source documents.

${ }^{a}$ Currency share data are publically unavailable for the Bank of Canada in 2000, so 2003 data are given instead.

b Other currencies held by the Swiss National Bank include the British pound, Canadian dollar, and Danish kroner.

that the composition of its foreign currency reserves must match the government's foreign currency-denominated liabilities. Japan, Switzerland, and the euro area do not disclose whether or not they have target currency allocations. The United States does not actively manage the currency composition of its reserves, but instead leaves reserves in the currency in which they were initially obtained.

We've seen that all countries limit the assets in which foreign exchange reserves can be held. These restrictions are rooted in the shared goal of having highly liquid positions. The countries reviewed in this article can invest their foreign currency reserves in government bonds and supranational bonds ${ }^{5}$ such as those issued by the International Monetary Fund, the World Bank, or regional multilateral development banks. Japan and the United States can invest their reserves in a relatively narrow group of assets, while other countries - Canada, the euro area, and Switzerland-have actively introduced broader investment opportunities for their portfolios. Two major developments in asset composition in the last decade have been increased diversification of allowable asset classes and the expanded use of derivatives to manage reserve portfolios more actively.

For example, the Swiss National Bank has a fairly broad range of fixed-income instruments it can invest in, including government bonds, covered bonds, bonds issued by foreign

\footnotetext{
${ }^{5}$ U.S. reserves must be held in assets that are "obligations of, or fully guaranteed as to principal and interest by, a foreign government or agency thereof" (Federal Reserve Act, sec. 14).
} 
local authorities and supranational organizations. ${ }^{6}$ Over the last decade, the SNB expanded the list of eligible assets to include corporate bonds in 2004 and equities in $2005 .^{7}$ This change in asset allocation resulted from the elimination of legal restrictions on eligible investments in 2004-a move that allowed the SNB to improve the risk/return profile of its investments. ${ }^{8}$

Several central banks utilize derivatives to manage their portfolios more actively or to mitigate risks. The Swiss National Bank is authorized to use equity futures to manage its equity investments. ${ }^{9}$ Other central banks have stayed with more traditional interest rate and foreign exchange derivatives. For example, in managing the United Kingdom's Exchange Equalisation Account, the Bank of England can use foreign exchange forwards, interest rate and currency swaps, overnight indexed swaps, bond and interest rate futures, swap notes and swap futures, and forward rate agreements. ${ }^{10}$ The Bank of Canada can also employ derivatives in managing its reserves; specifically, foreign exchange and cross-currency swaps are used for funding and currency hedging purposes. ${ }^{11}$

A challenge for each country is to have a portfolio that balances the benefits of short-term liquidity and safety against the costs of earning lower investment returns than might arise with a broader set of asset holdings. Such opportunity costs presumably increase with the restrictiveness of the investment portfolios,

\section{Several central banks utilize derivatives to manage their portfolios more actively or to mitigate risks.}

and are magnified as portfolios grow in size. Limited information is available for comparing foreign exchange reserve portfolio returns across countries. However, we can derive some suggestive information on the consequences of restricting the investment composition of the euro and yen portfolios of the United States and Canada. ${ }^{12}$ The Federal Reserve publishes both the quarterly

\footnotetext{
${ }^{6}$ Swiss National Bank, "Foreign Exchange Reserves and Swiss Franc Securities," available at http://www.snb.ch/en/iabout/assets/id/assets_reserves.

${ }^{7}$ Swiss National Bank, Ninety-Eighth Annual Report 2005, available at http://www .snb.ch/en/mmr/reference/annrep_2005_komplett/source.

${ }^{8}$ Swiss National Bank, Ninety-Seventh Annual Report 2004, available at http:// www.snb.ch/en/mmr/reference/annrep_2004_komplett/source.

${ }^{9}$ Swiss National Bank, "Foreign Exchange Reserves and Swiss Franc Securities," available at http://www.snb.ch/en/iabout/assets/id/assets_reserves.

${ }^{10}$ Bank of England, “Composition of Reserves," http://www.bankofengland.co.uk/ markets/Pages/forex/reserves/composition_reserves.aspx.

${ }^{11}$ Department of Finance Canada, Report on the Management of Canada's Official International Reserves, 2011-12, available at http://www.fin.gc.ca/activty/oirrep/ oir-roli-12-eng.pdf.

${ }^{12}$ Switzerland makes information available on the returns to its entire portfolio without differentiating returns for the portfolios in specific currencies. Canadian
}

Chart 2

\section{Euro and Yen Portfolio Returns, Bank of Canada and the Federal Reserve: 2003-12}

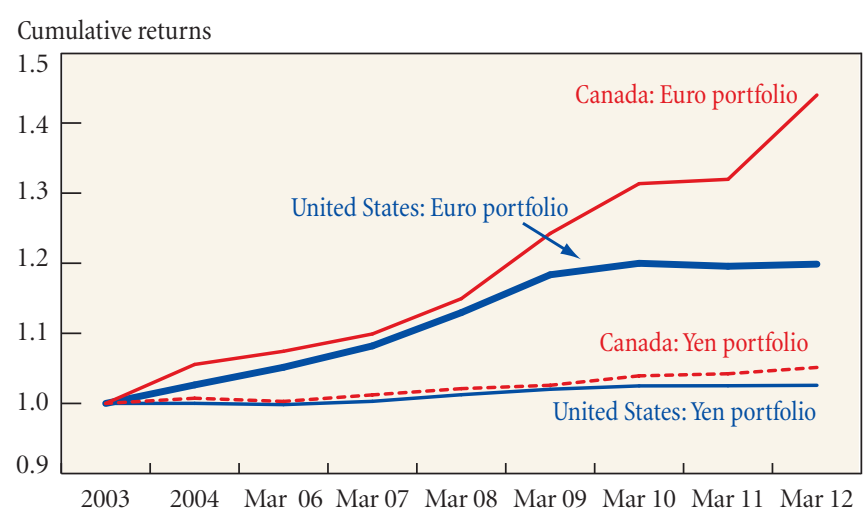

Sources: Department of Finance Canada, Report on the Management of Canada's Official International Reserves, 2004-12; Federal Reserve Bank of New York.

Notes: The chart shows the cumulative euro and yen portfolio returns realized by the United States and Canada (with 2003 set equal to 1). Furthermore, because the date units for Canada are not exactly yearly, the following units have been used for both the United States and Canada from 2003 to 2009: January 1, 2003-December 31, 2003; January 1, 2004-December 31, 2004; January 1, 2005-March 31, 2006; April 1, 2006March 31, 2007; April 1, 2007-March 31, 2008; April 1, 2008-March 31, 2009; April 1,2009-March 31, 2010; April 1, 2010-March 31, 2011; and April 1, 2011March 31, 2012.

breakdown of foreign reserve assets held and the changes in balance by source (net purchases and sales, investment earnings, realized gains or losses on sales, and unrealized gains or losses from foreign currency revaluation). ${ }^{13}$ The Bank of Canada provides a decomposition of returns at an annual frequency, separating returns in U.S. dollar portfolios from those in euros or in yen. The Bank of Canada also provides liability benchmarks by currency for comparison with actual performance. This information facilitates a comparison of returns within euro assets and within yen assets.

Chart 2 shows the differences in cumulative returns on euro and yen portfolio investments by the Federal Reserve and the Bank of Canada. Taking the end of 2003 as a starting point (and setting it equal to 1 for comparison purposes), we observe that the type of asset allocation undertaken by Canada appears to have produced returns on its yen portfolio similar to those realized by the United States. Given these relatively similar returns in yen, it seems likely that Canada's yen portfolio, like the corresponding U.S. portfolio, is invested mostly in Japanese government bonds. By contrast, Canada may have realized superior returns with respect to its euro portfolios; the cumulative nominal value of the

data are reported in Department of Finance Canada, Report on the Management of Canada's Official International Reserves, 2004-09, available at http://www.fin.gc.ca/ activty/oirrep/oir-roli-10-index-eng.asp.

${ }^{13}$ See http://www.newyorkfed.org/newsevents/news/markets/2010/fxq310.pdf. 
Canadian euro portfolio grew overall by 44 percent, compared with just 20 percent for the U.S. euro portfolio over a comparable interval. Canada's euro portfolio likely provided greater scope for gains because of its larger universe of liquid fixed-income products, which carry higher credit risk than government securities but also yield higher returns. Overall, the evidence presented here suggests that allowing broader classes of investments in portfolios could reduce some of the opportunity costs of maintaining large balances of foreign exchange reserves.

\section{Conclusion}

The idea that a central bank should hold foreign currency reserves is widely accepted. Indeed, it is a central feature of the post-Bretton Woods international financial order. Nonetheless, as this article demonstrates, identifying what is optimal in the foreign exchange reserve practices of industrialized economies can be quite difficult.

Further work on the relationship between countries' objectives in holding foreign exchange reserves and the size - whether "small" or "large" — of reserve holdings might be useful given the rapid growth and evolution of international financial markets and cooperative arrangements across central banks. If foreign currency reserve holdings are intended primarily for use in intervention actions that affect exchange rates through a signaling channel, perhaps small reserve portfolios might suffice. But if countries continue to accumulate large portfolios, then the opportunity cost of these holdings and their effectiveness in advancing foreign exchange reserve objectives might be further analyzed. The opportunity costs posed by large reserve portfolios might include not only low rates of return on large pools of country assets, but also the exposure of central banks and ultimately taxpayers to movements in exchange rates. Either way, the academic and policy communities would do well to engage in constructive discussion of the issues surrounding the size and composition of industrialized economies' foreign exchange reserve portfolios. Overall, considerable uncertainty exists about the level of foreign currency reserves needed by industrialized countries for possible interventions in the foreign exchange market and the level that reserve balances should resume after periods of prolonged reserve accumulation.

\section{Appendix Table: Sample Countries' Foreign Exchange Interventions}

\begin{tabular}{|c|c|}
\hline Country & Interventions \\
\hline Canada & $\begin{array}{l}\text { "Canada's current policy is to intervene in foreign exchange markets on a discretionary, rather than systematic, basis and only in the most } \\
\text { exceptional of circumstances... The last time the Bank intervened in foreign exchange markets to affect movements in the Canadian dollar was } \\
\text { in September 1998.... In September 2000, the Bank of Canada joined the European Central Bank, the Federal Reserve Bank of New York, the } \\
\text { Bank of Japan, and the Bank of England in a concerted intervention to support the euro.... In March 2011, the Bank of Canada joined authorities } \\
\text { in the U.S., the U.K., Europe and Japan in a concerted intervention to stabilize the Japanese currency." }\end{array}$ \\
\hline United Kingdom & $\begin{array}{l}\text { "The Government has not intervened for the purposes of influencing the sterling exchange rate since 1992." } \\
\text { "Intervention was undertaken ... on } 22 \text { September 2000, when the Bank of England ... purchased } € 85 \text { million against sterling. This action was } \\
\text { taken as part of concerted intervention by the G7 [Group of Seven] monetary authorities." } \\
\text { "On } 18 \text { March 2011, the Bank of England acting as agent for HM Treasury, and at the request of the Japanese authorities, joined Japan and the } \\
\text { authorities of the United States, Canada and the European Central Bank in a concerted G7 intervention in foreign exchange markets." }\end{array}$ \\
\hline Japan & $\begin{array}{l}\text { The Ministry of Finance conducted foreign exchange interventions in 2000, 2001, 2002, 2003, and 2004, but not from } 2005 \text { to } 2009 \text {. However, } \\
\text { starting in September 2010, Japan intervened once again, buying Japanese yen with U.S. dollars in September 2010, March 2011, August 2011, } \\
\text { October 2011, and four times in November 2011. }\end{array}$ \\
\hline Euro Area & $\begin{array}{l}\text { In 2000, the European Central Bank (ECB) conducted foreign exchange interventions on September } 22 \text { and November 3, 6, and 9, but the size of } \\
\text { the transactions has not been released publicly. The effort was coordinated with other countries, including the United States and Japan. On March } \\
18,2011 \text {, the ECB participated in a concerted international intervention in the foreign exchange markets to help stabilize the Japanese yen. }\end{array}$ \\
\hline Switzerland & $\begin{array}{l}\text { On March 12,2009, the Swiss National Bank (SNB) announced that it intended to intervene in foreign currency markets to stem the appreciation } \\
\text { of the Swiss franc. This was the first time the bank had intervened since August 1995. Furthermore, on September 6, 2011, the SNB pegged } \\
\text { its minimum exchange rate at CHF } 1.20 \text { per euro, stating that "the SNB will enforce this minimum rate with the utmost determination and is } \\
\text { prepared to buy foreign currency in unlimited quantities." }\end{array}$ \\
\hline United States & $\begin{array}{l}\text { The United States intervened in the foreign exchange market in } 2000 \text { to buy euros and sell U.S. dollars. This was part of a coordinated effort with } \\
\text { the European Central Bank and other large central banks to support the value of the euro. In addition, in } 2011 \text { "the U.S. monetary authorities } \\
\text { intervened in the foreign exchange markets ... on March 18, buying \$1 billion against Japanese yen" as part of a coordinated G7 intervention. }\end{array}$ \\
\hline
\end{tabular}

Sources: Bank of Canada Backgrounders: Intervention in the Foreign Exchange Market (http://www.bankofcanada.ca/wp-content/uploads/2010/11/intervention_foreign _exchange.pdf); Her Majesty's Treasury, Debt and Reserves Management Report, 2010-11, Exchange Equalisation Account: Report and Accounts, 2000-01, and Exchange Equalisation Account: Report and Accounts, 2010-11; Ministry of Finance Japan, Foreign Exchange Intervention Operations (http://www.mof.go.jp/english/international_policy/reference/ feio/index.htm); European Central Bank, annual reports, 2000-2011; Swiss National Bank, annual reports, 2000-2009, and press release, "Swiss National Bank Sets Minimum Exchange Rate at CHF 1.20 per Euro," September 6, 2011 (http://www.snb.ch/en/mmr/reference/pre_20110906/source/pre_20110906.en.pdf); Federal Reserve Bank of New York, Treasury and Federal Reserve Foreign Exchange Operations Quarterly Reports (http://www.newyorkfed.org/markets/quar_reports.html). 


\section{References}

Aizenman, Joshua. 2008. “Large Hoarding of International Reserves and the Emerging Global Economic Architecture." The Manchester School 76, no. 5 (September): 487-503.

Bank for International Settlements. 2010. BIS Triennial Central Bank Survey, November.

Dominguez, Kathryn. 2003. "Foreign Exchange Intervention: Did It Work in the 1990s?” In C. Fred Bergsten and John Williamson, eds., Dollar Overvaluation and the World Economy, 217-45. Washington, D.C.: Institute for International Economics.

.2006. "When Do Central Bank Interventions Influence Intra-Daily and Longer-Term Exchange Rate Movements?” Journal of International Money and Finance 25, no. 7 (November): 1051-71.

Goldberg, Linda. 2010. “Is the International Role of the Dollar Changing?” Federal Reserve Bank of New York Current Issues in Economics and Finance 16, no. 1 (January).

Goldberg, Linda, Mark Choi, and Hunter Clark. 2011. "What If the U.S. Dollar's Global Role Changed?” Federal Reserve Bank of New York Liberty Street Economics blog, October 3 .
Goldberg, Linda, Craig Kennedy, and Jason Miu. 2011. “Central Bank Dollar Swap Lines and Overseas Dollar Funding Costs." Federal Reserve Bank of New York Economic Policy Review 17, no. 1:3-20.

McGuire, Patrick, and Gotz von Peter. 2009. “The U.S. Dollar Shortage in Global Banking and the International Policy Response." Bank for International Settlements, BIS Working Papers, no. 291, October.

Menkhoff, Lukas. 2010. "High-Frequency Analysis of Foreign Exchange Interventions: What Do We Learn?” Journal of Economic Surveys 24, no. 1: 85-112.

Sarno, Lucio, and Mark Taylor. 2001. "Official Intervention in the Foreign Exchange Market: Is It Effective and, If So, How Does It Work?” Journal of Economic Literature 39, no. 3 (September): 839-68.

Truman, Edwin. 2003. “The Limits of Exchange Market Intervention.” In C. Fred Bergsten and John Williamson, eds., Dollar Overvaluation and the World Economy, 247-65. Washington, D.C.: Institute for International Economics.

\section{ABOUT THE AUTHORS}

Linda Goldberg is a vice president in the Research and Statistics Group of the Federal Reserve Bank of New York; Cindy E. Hull is a policy and market analysis senior associate in the Markets Group; Sarah Stein is a research associate in the Research and Statistics Group.

The content co-editor of this article is Matthew Higgins.

Current Issues in Economics and Finance is published by the Research and Statistics Group of the Federal Reserve Bank of New York. Linda Goldberg and Thomas Klitgaard are the editors of the series.

Editorial Staff: Valerie LaPorte, Mike De Mott, Michelle Bailer, Karen Carter, Anna Snider

Production: Jane Urry, Jessica lannuzzi, David Rosenberg

Back issues of Current Issues are available at http://www.newyorkfed.org/research/current_issues/.

The views expressed in this article are those of the authors and do not necessarily reflect the position of the Federal Reserve Bank of New York or the Federal Reserve System. 


\section{RELATED READINGS FROM THE FEDERAL RESERVE BANK OF NEW YORK}

Publications of the Research and Statistics Group Available at http://www.newyorkfed.org/research/publication _annuals/index.html

Central Bank Dollar Swap Lines and Overseas Dollar Funding Costs

Linda Goldberg, Craig Kennedy, and Jason Miu

Economic Policy Review, vol. 17, no. 1,2011

With the onset of the financial crisis in 2007, foreign banks saw a sharp reduction in their access to dollar funding - a development that had potentially dire consequences for financial markets and real activity associated with banking. In response, the Federal Reserve established central bank dollar swaps: reciprocal currency arrangements with several foreign central banks that were designed to ameliorate dollar funding stresses overseas. This study provides an overview of the swap facilities and assesses the economic research documenting the efficacy of the program. The authors conclude that the dollar swap facilities played an important role in minimizing systemic liquidity disruptions.

\section{The Federal Reserve's Foreign Exchange Swap Lines}

Michael J. Fleming and Nicholas J. Klagge

Current Issues in Economics and Finance, vol. 16, no. 4, April 2010

The financial crisis that began in August 2007 disrupted U.S. dollar funding markets not only in the United States but also overseas. To address funding pressures internationally, the Federal Reserve introduced a system of reciprocal currency arrangements, or "swap lines," with other central banks. The swap line program, which ended early this year, enhanced the ability of these central banks to provide U.S. dollar funding to financial institutions in their jurisdictions.

Is the International Role of the Dollar Changing?

Linda Goldberg

Current Issues in Economics and Finance, vol. 16, no. 1, January 2010.

Recently the U.S. dollar's preeminence as an international currency has been questioned. The emergence of the euro, changes in the dollar's value, and the financial market crisis have, in the view of many commentators, posed a significant challenge to the currency's long-standing position in world markets. However, a study of the dollar across critical areas of international trade and finance suggests that the dollar has retained its standing in key roles. While changes in the global status of the dollar are possible, factors such as inertia in currency use, the large size and relative stability of the U.S. economy, and the dollar pricing of oil and other commodities will help perpetuate the dollar's role as the dominant medium for international transactions.
Reserve Accumulation: Implications for Global Capital Flows and Financial Markets

Matthew Higgins and Thomas Klitgaard

Current Issues in Economics and Finance, vol. 10, no. 10, September-October 2004

Many central banks-particularly those in Japan and the emerging Asian nations - have been building up their holdings of foreign currency assets. These holdings, known as foreign exchange reserves, may help countries stabilize their currencies, but they can also lead to investment losses for the central banks. The large share of dollar assets among reserve holdings has made foreign central banks important players in U.S. financial markets.

\section{The Liberty Street Economics Blog}

Available at http://libertystreeteconomics.newyorkfed.org/

What If the U.S. Dollar's Global Role Changed?

Linda Goldberg, Mark Choi, and Hunter Clark

Liberty Street Economics blog, October 3, 2011

The authors consider the implications for the United States of a lessening in the dollar's primacy in international transactions. They conclude that if the decline in the dollar's primacy were to occur in the context of strong U.S. growth and institutional fundamentals, it would not be a significant threat to the country's economic well-being. However, the decline could have more adverse effects if the dollar's reduced role were to be associated with less auspicious U.S. policy choices and weaker economic fundamentals. These effects would be seen most clearly in higher U.S. funding costs and increased sensitivity of the domestic economy to developments in foreign markets.

\section{Operations Reports}

Available at http://www.newyorkfed.org/markets/quar_reports.html

Treasury and Federal Reserve Foreign Exchange Operations Quarterly Reports

The Federal Reserve Bank of New York manages U.S. foreign currency reserves and carries out foreign exchange-related activities on behalf of the Federal Reserve System and the U.S. Treasury. Each quarter, reports are released describing currency developments and foreign exchange operations over the period. 